\title{
AZ ANTROPOGÉN EREDETÚ ANYAGOK VIZSGÁLATA DEBRECEN TALAJAIBAN
}

\section{THE INVESTIGATION OF ANTHROPOGENIC MATERIALS IN THE SOILS OF DEBRECEN}

\author{
Sándor Gábor ${ }^{1}$, Szabó György ${ }^{2}$ \\ Debreceni Egyetem, Tájvédelmi és Környezetföldrajzi Tanszék, Magyarország, \\ 4032, Debrecen, Egyetem tér 1; Telefon: (52) - 512 - 900 / 22235 Fax: (52) - 512 - \\ 945 \\ ${ }^{1}$ sanyigabi7@gmail.com \\ ${ }^{2}$ szabo.gyorgy@science.unideb.hu.
}

\begin{abstract}
In our study we examined the anthropogenic materials in the soils of Debrecen. We observed significant differences between the properties of soil samples with artefact and without it. We investigated the relationship among the artefact content and the acidity and the calcium carbonate content of the soils in Debrecen. The correlation analisys showed that the higher $\mathrm{pH}$ values depend on the artefact content with high calcium carbonate. We established, the human impact has an effect on the distribution of $\mathrm{pH}$ of soils..
\end{abstract}

Keywords: artefact content, urban soil, $p H$, calcium carbonate

\section{Összefoglalás}

Tanulmányunkban az antropogén eredetủ anyagok szerepét vizsgáltuk Debrecen talajaiban. A szelvényeink rendkívül nagy bolygatottságot mutattak, amit az erős antropogén hatás eredményezett. Meghatároztuk a begyüjtött talajminták müterméktartalmát, kémhatását és kalcium-karbonát tartalmát. A két utóbbi talajtulajdonság alakulásában jelentős különbségeket fedeztünk fel a mütermékkel rendelkező és a müterméktől mentes talajminták esetében. A magasabb müterméktartalommal rendelkező talajmintáknál általában magasabb pH-t és kalcium-karbonát-tartalmat sikerült kimutatni. A laboratóriumi eredményeket statisztikai elemzésnek vetettük alá. A korrelációs vizsgálatok kimutatták, hogy a magasabb $\mathrm{pH}$ hátterében a magas kalcium-karbonát-tartalmú mütermékek állnak, tehát a talajok kémhatásának alakulásában az antropogén hatás egyértelműen kimutatható

Kulcsszavak: mütermék, városi talaj, kémhatás, kalcium-karbonát tartalom

\section{Bevezetés}

Városaink terjeszkedése nagyban hozzájárul a környezet megváltozásához. Az építkezések alkalmával gyakran szükség van tereprendezési munkálatokra. A terepegyengetés során a talajok is sérülhetnek. A feltöltésből adódóan számolnunk kell a mesterséges anyagok mennyiségi növekedésével vagy akár egy teljesen új kultúrréteg kialakulásával is. Másrészt a magasabb térszínek elegyengetésével, elhordásával a talaj egy mélyebb szintje kerül felszínre, amelyet így az antropogén hatások közvetlenül is érintenek [1]. A debreceni talajok vizsgálata során föleg az épületek 
és a közlekedési pályák építésének nyomaival találkozhatunk. Az építkezésekből viszszamaradt bontási törmelék és anyagmaradékok (vakolat, tégla, cement, gipsz) jelentős mennyiségben tartalmaznak meszet, ami negatív irányba módosíthatja a talaj egyes tulajdonságait [2]. Az antropogén hatásra módosult talajtulajdonságokkal és a mütermékek talajban való előfordulásával több hazai és külföldi kutató is foglalkozott $[3,4,5,6]$

Tanulmányunkban azt vizsgáltuk, hogy a mütermékek jelenléte befolyásolja-e a talajok kémhatását, hogy ebben a tekintetben megfigyelhetö-e valamilyen különbség a nagy mennyiségü építési és bontási törmelékkel rendelkező talajok és a mütermékmentes talajok között.

\section{Anyag és módszer}

2012 augusztusától 2013 júniusáig 18 talajszelvényt mintáztunk meg Debrecen területén (1. ábra). A szelvények helyét próbáltuk úgy megválasztani, hogy azok arányosan fedjék le a mintaterületünket. $\mathrm{Az}$ egyes szelvények mélysége 1 és $2 \mathrm{~m}$ között változott. $\mathrm{A}$ mintákat 20 centiméterenként vettük, így összesen 113 darab mintát gyüjtöttünk be. A szelvények többségénél megfigyelhetö egy mesterséges, kemény technikai réteg (járda, útburkolat), amely esetünkben néhol a $40 \mathrm{~cm}$ vastagságot is elérheti. A laboratóriumi munkálatokat a Debreceni Egyetem Tájvédelmi és Környezetföldrajzi Tanszékének Talajtani Laboratóriumában végeztük. A vizsgálatok során a talajmintákat $40{ }^{\circ} \mathrm{C}$-on kiszárítottuk, majd 2 mm-es átmérőjü szitán átszitáltuk. Az így különválasztott antropogén eredetủ anyagok tömegét az eredeti minta tömegéhez viszonyítottuk, és százalékos értéket számolva megkaptuk a müterméktartalmat. Tehát a mintákból eltávolítottuk az antropogén eredetủ anyagokat, $\mathrm{s}$ a további vizsgálatokhoz már csak az így nyert földes részt használtuk fel. A talaj $\mathrm{pH}$-ját elektromos $\mathrm{pH}-$ mérővel mértük desztillált vizes és $\mathrm{KCl}$-os szuszpenzióban, a $\mathrm{CaCO}_{3}$ tartalmát 10\%-os sósav hozzáadásával, Scheibler-féle kalciméterrel határoztuk meg.

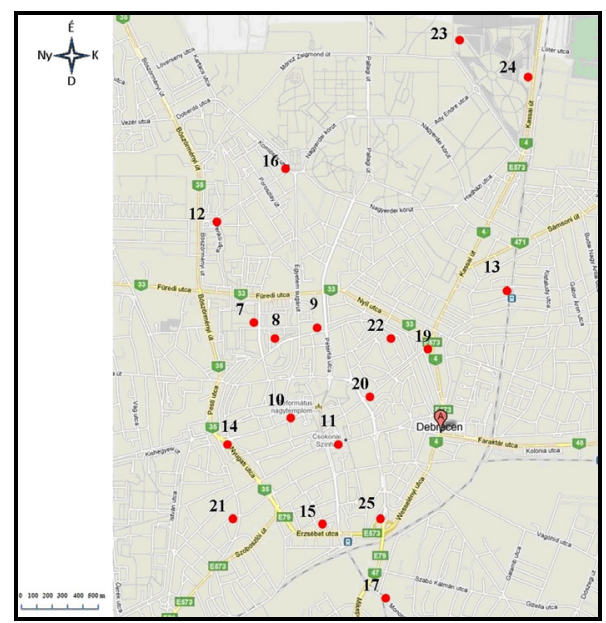

1. ábra. A szelvények elhelyezkedése

\section{Mintaterület jellemzése}

Debrecen a Hajdúság és a Nyírség határán fekvő, több mint 200000 fös város. Az eltérő táji adottságok a talajtani viszonyokra is hatással vannak, hiszen a nyírségi futóhomokos területeken döntően futóhomok váztalajok és humuszos homoktalajok borítják a felszínt. A löszös síkságainkon, így a Hajdúságban is a leggyakrabban előforduló talajtípusok a csernozjomok. A Hajdúságban a felszínhez közeli talajvízszintek jellemzőek, az alacsony térszíneken csapadékosabb időszakban a belvízveszéllyel is számolni kell. A magas sótartalmú talajvizekhez elsősorban a mélyben sós réti csernozjom és a mélyben sós alföldi mészlepedékes csernozjom megjelenése köthető [7]. A mai belváros területén korábban négy különálló falu osztozott, azonban ezekböl mára szinte semmi sem maradt meg. A belváros központi része, a mai Kossuth tér, egy alacsonyan fekvő buckaközi, vizenyős mé- 
lyedés volt, ahol csak pallókon lehetett közlekedni. A terület az évszázadok folyamán lassan feltöltődött, s ma már 2-3 méteres mélységben találjuk csak meg az eredeti talajfelszínt [8]. A belváros központi részét övező területek már magasabb térszínen fekszenek, ezért itt a kultúrréteg vastagsága általában kisebb. A talajfedés aránya a városközpontban a legmagasabb, kb. $75 \%$. A belvárosi területen az úthálózat alapvetően sugaras szerkezetü. A beépítés jellege többnyire 2-4 emeletes lakótömbökböl és zárthomlokzatú utcára néző lakóházakból áll. Amíg a keleti városrészen a kertes családi házas beépítés jellemző, addig a nyugati oldalon a lakótelepek 4-14 emeletes panelházai uralkodnak. A mesterséges talajfedés aránya a keleti oldalon döntően $50 \%$ alatt van, nyugaton ugyan ez az érték 50-75\% között mozog [9].

\section{Eredmények}

A debreceni talajszelvényeket vizsgálva megállapítottuk, hogy a $\mathrm{pH}$ átlagos értéke 8,07 tehát a gyengén lúgos tartományba sorolható. A mésztartalom szélsőséges értékeket mutat, a minimum érték $1,95 \%$ a maximum 16,85\%.

1.táblázat. A vizsgált talajtulajdonságok statisztikai mutatói

\begin{tabular}{|l|c|c|c|c|}
\hline $\begin{array}{c}\text { Statisztikai } \\
\text { mutatók / } \\
\text { Talaj- } \\
\text { tulajdonságok }\end{array}$ & $\begin{array}{c}\text { Müter- } \\
\text { mék } \\
\mathbf{( \% )}\end{array}$ & $\mathbf{p H} \mathbf{H}_{\mathbf{2}} \mathbf{O}$ & $\begin{array}{c}\mathbf{p H} \\
\mathbf{K C l}\end{array}$ & $\begin{array}{c}\mathbf{C a C O}_{3} \\
\mathbf{( \% )}\end{array}$ \\
\hline Átlag & 5,35 & 8,07 & 7,74 & 5,67 \\
\hline Medián & 3,30 & 8,22 & 8,00 & 5,09 \\
\hline Módusz & 0,00 & 8,31 & 8,40 & 10,85 \\
\hline $\begin{array}{l}\text { Minimum } \\
\text { érték }\end{array}$ & 0,00 & 6,32 & 5,19 & 1,95 \\
\hline Maximum & 37,24 & 8,95 & 8,68 & 16,85 \\
\hline Érték
\end{tabular}

A müterméktartalom esetében is előfordulnak kiugró eredmények, azonban az átlagos érték alig haladja meg az 5\%-ot (1. táblázat).
Az építkezési törmelékek, anyagmaradékok gyakran magas mésztartalommal rendelkeznek, így a talajba kerülve megnövelhetik annak kalciumtartalmát és $\mathrm{pH}$ értékét [10]. A magas mésztartalom bázikus kémhatást idézhet elö, a két paraméter között így egyértelmü az összefüggés [11]. A belvárosi szelvények nagy része tartalmazott mütermékeket, amelyek föleg építési, bontási törmelékek voltak (2. ábra).
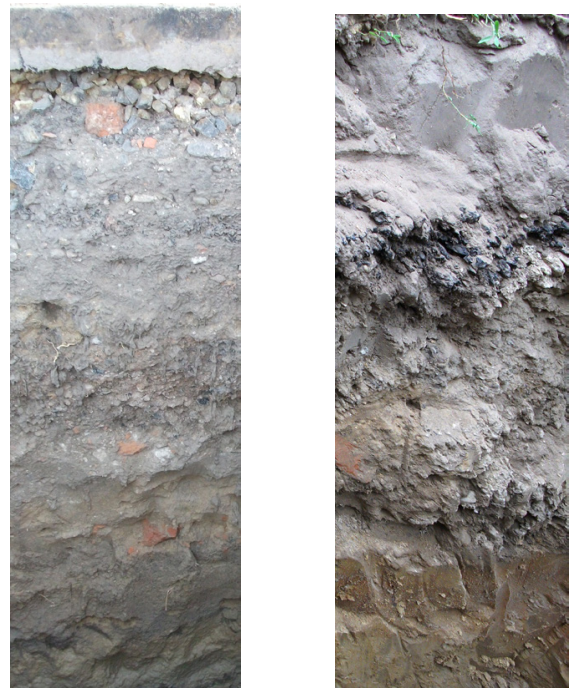

2. ábra. Mütermékek a 17-es és a 12-es szelvényben

Az antropogén anyagok részaránya általában a mélyebb rétegek felé csökkent, több esetben 80-100 cm-es mélységben már nem is találtunk müterméket (20-as, 8-as, 12-es és 13-as szelvény) (3. ábra).

A megmintázott szelvények müterméktartalma rendkívül nagy változatosságot mutatott. Egyes helyeken, mint például a Városi Köztemető az elmúlt néhány évben használatba vett területén található két szelvény egyikében sem volt antropogén eredetü anyag (23-as és 24-es szelvény). 


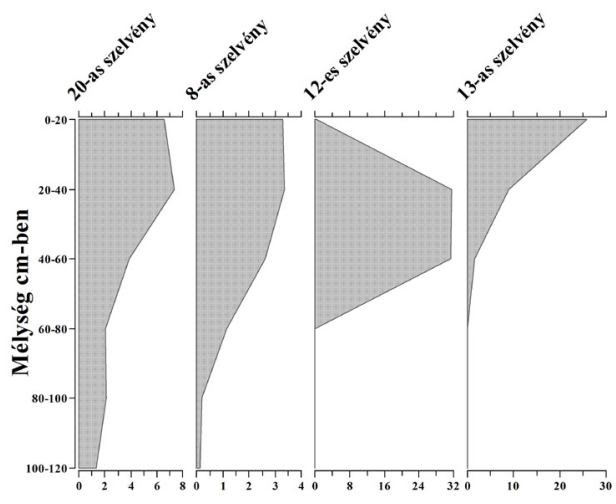

3. ábra. A müterméktartalom eloszlása (\%) a 20-as, 8-as, 12-es és a 13-as szelvényekben

Ezen nemcsak a vizsgálatainkban fontos szerepet játszó paramétereket (mésztartalom, pH) befolyásoló magas mésztartalommal rendelkező anyagokat értjük, hanem minden olyan anyagot is, amely antropogén hatás következtében kerül a talajba. Más kutatók kimutatták, hogy a koporsókon található fémből készült részek (szegek, fogantyúk, kilincsek egyéb dísztárgyak) szerepet játszhatnak a talaj nehézfémszennyezésében [12], emellett arra is rámutattak, hogy a patogén eredetü anyagok megnövelhetik a talaj szervesszén-tartalmát [13].

A talajminták laboratóriumi vizsgálati eredményei alapján két csoportot alakítottunk ki. Az egyikbe azokat a mintákat so-

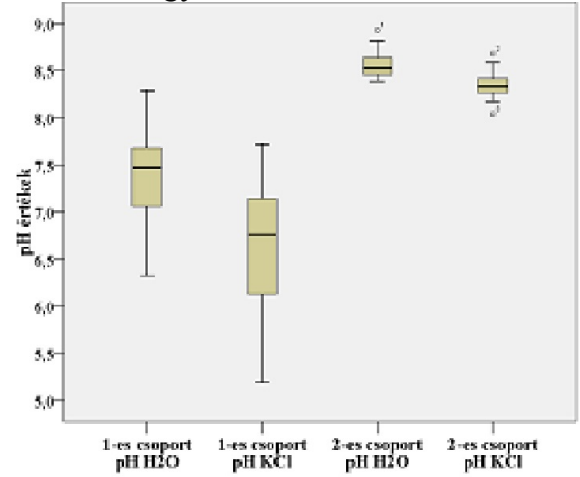

roltuk (1-es csoport), amelyekben nem volt antropogén eredetü anyag (25 darab), míg a másikba olyan minták kerültek (2-es csoport), amelyekben a talált mütermékek feltételezhetően, felelősek lehetnek a talaj mésztartalmának és kémhatásának az alakulásáért, ezek döntően magas kalciumkarbonát-tartalommal bíró építési és bontási törmelékek voltak (74 darab). A maradék 14 darab mintát nem vontuk be a vizsgálatba, mert a bennük talált mütermékek (üveg, fém, mủanyag) nem tartalmaztak karbonátos anyagokat. A kapott adathalmazt statisztikai vizsgálatoknak vetettük alá. Az alapstatisztikai mutatókból azt olvashatjuk le, hogy az 1-es csoportban a pH- és a mésztartalom esetében is jelentősen alacsonyabb volt a medián, a minimum és a maximum érték, mint a 2-es csoportban. Az 1-es csoport néhány mintájának $\mathrm{pH}$-ja igen alacsonynak mondható $(\mathrm{pH}<7)$, messze elmarad a városi talajokra jellemző enyhén lúgos és lúgos tartománytól. Ezek a minták a Városi Köztemető területén található két szelvényből származnak. Egyik szelvény esetében sem figyeltünk meg komolyabb, emberi hatásra utaló bolygatást. A mütermékeket tartalmazó minták túlnyomó része gyengén lúgos és lúgos kémhatású (4. ábra).

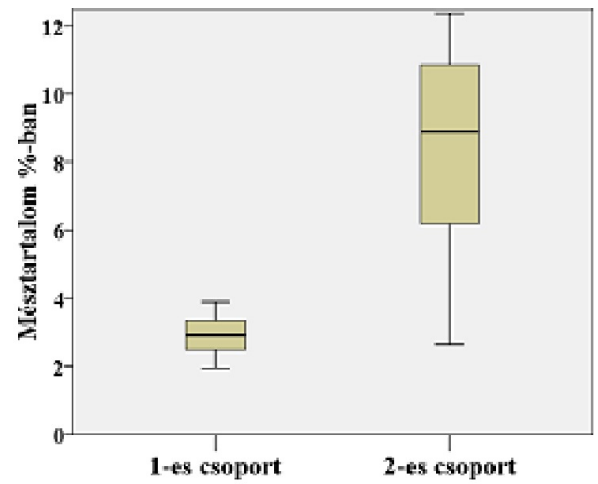

4. ábra. Az 1-es és 2-es csoport kémhatása és mésztartalma 
A továbbiakban a két csoport adataiból Spearman-féle rangkorrelációt számoltunk. Az 1-es csoport esetében csak a desztillált vizes és a kálium-kloridos szuszpenzióban mért pH-értékek között sikerült erős korrelációs kapcsolatot kimutatni $(\mathrm{r}=0,75$, $\mathrm{p}<0,01)$. Ugyanakkor a 2-es csoport esetében a $\mathrm{pH}$ értékek alakulása szoros pozitív korrelációs kapcsolatot mutatott a mésztartalommal, emellett szintén pozitív korrelációs kapcsolat figyelhető meg a $\mathrm{pH}(\mathrm{KCl})$ és a mütermék-tartalom között. A mütermékek és a mésztartalom között megfigyelhető egy szignifikáns összefüggés, bár az nem olyan erős, mint az előző esetekben.

2. táblázat. A 2-es csoport korrelációs

\begin{tabular}{|l|r|r|r|r|}
\hline Talajtulajdonságok & $\mathrm{pH} \mathrm{H} \mathrm{H}_{2} \mathrm{O}$ & $\mathrm{pH} \mathrm{KCl}$ & $\begin{array}{l}\mathrm{CaCO}_{3} \\
(\%)\end{array}$ & \multicolumn{2}{|l|}{$\begin{array}{l}\text { Müterméktartalom } \\
(\%)\end{array}$} \\
\hline $\mathrm{pH} \mathrm{H} \mathrm{H}_{2} \mathrm{O}$ & & $0,8^{* *}$ & $0,49 * *$ & 0,12 \\
\hline $\mathrm{pH} \mathrm{KCl}$ & $0,8^{* *}$ & & $0,53 * *$ & $0,27 *$ \\
\hline $\mathrm{CaCO}_{3}(\%)$ & $0,49 * *$ & $0,53 * *$ & & $0,27 *$ \\
\hline $\begin{array}{l}\text { Müterméktartalom } \\
(\%)\end{array}$ & 0,12 & $0,27 *$ & $0,27 *$ & \\
\hline
\end{tabular}

\section{Következtetés}

A szelvények vizsgálata alapján megállapítottuk, hogy Debrecen talajai nagymértékü antropogén hatás alatt állnak. A szelvények döntő többségében számolnunk kell mütermékek jelenlétével, amelyek legnagyobb részét magas kalciumtartalmú építési és bontási törmelékek alkotják. A városi talajokra jellemző módon a kémhatás az enyhén lúgos és lúgos tartományba sorolható, valamint a mésztartalom is többnyire magas értékeket mutat. A korrelációs vizsgálatok arra engednek következtetni, hogy a magasabb $\mathrm{pH}$ hátterében a magas $\mathrm{CaCO}_{3}$ tartalmú mütermékek állnak, ugyanakkor a mütermékek tényleges százalékos aránya és a pH alakulása közötti kapcsolat nem különösebben erős. Összességében azonban kijelenthetjük, hogy a talajok kémhatásának és mésztartalmának alakulásában az antropogén hatás kimutatható.

\section{Szakirodalmi hivatkozások}

[1] Szabó, J.: A települések hatásai. In: A társadalom hatása a földfelszínre (antropogéngeomorfológia) - szerk. Borsy Z. Általános Természetföldrajz, 1998, 832.
[2] Magyar Cementipari Szövetség, http://www.mcsz.hu/index.php?menu=2\&old $\underline{\mathrm{al}=5}, 2013$

[3] Szegedi, S.: Közlekedési eredetü nehézfémek Debrecen talajaiban és növényzetében, ennek talajtani összefüggései és városökológiai hatásai. Doktori értekezés. - Kossuth Lajos Tudományegyetem Alkalmazott Tájföldrajzi Tanszék, Debrecen, 1999. 138.

[4] Puskás, I., Prazsák, I., Farsang, A., Maróy, P.: Physical, chemical and biological aspects of human impacts on urban soils of Szeged. Journal of Environmental Geography, Vol.1.(1-2), 2008., 11-21.

[5] Jim, C. Y.: Urban soil characteristics and limitations for landscape planting in Hong Kong. Landscape and Urban Planning 40.4, 1998., 235-249.

[6] Howard, J. L., Olszewska, D.: Pedogenesis, geochemical forms of heavy metals, and artifact weathering in an urban soil chronosequence. Detroit, Michigan. Environmental Pollution 159, 2011., 754-761.

[7] Martonné, E. K.: Magyarország tájföldrajza. Kossuth Egyetemi Kiadó, Debrecen, 2008, 192.

[8] Csorba, P.: Városökológiai sétaút Debrecenben. Meridián Alapítvány, Debrecen, 2008., 44. 
[9] Szegedi, S.: $\quad A \quad$ debreceni hösziget jellegzetességei. Környezetvédelmi Mozaikok - Tiszteletkötet Dr. Kerényi Attila 60. születésnapjára, Debrecen, 2003., 383-389.

[10] Géczi, R.: Városi talajok. 2007., 1-10, http://www.geography.hu/geographer/geczi_r obert/GR varosi talajok.pdf

[11] Puskás I.: Városaink talajai: a szegedi talajok komplex értékelése és osztályozása. Doktori értekezés. Szegedi Tudományegyetem, Szeged, 2008., 154.
[12] Olivier, J., Jonker, C.: Mineral Contamination from Cemetery Soils: Case Study of Zandfontein Cemetery, South Africa. International Journal of Environmental Research and Public Health 9. 2012., 511-520.

[13] Charzyński, P., Bednarek, R., Świtoniak, M., Żołnowska, B.: Ekranic Technosols and Urbic Technosols of Toruń Necropolis. GEOLOGIJA, Lietuvos mokslų akademija, 2011., 179-185. 